\title{
Оцінка рівня коморбідності у хворих на гострий калькульозний холецистит із лапароскопічною холецистектомією
}

\begin{abstract}
Мета роботи: встановлення частоти наявності і рівня коморбідності у хворих із гострим калькульозним холециститом (ГКХ), яким проводили лапароскопічну холецистектомію.

Матеріали і методи. Прооперовано 457 хворих на гострий калькульозний холецистит, які перебували на стаціонарному лікуванні в міській лікарні № 2 м. Тернополя. Усім проведено клініко-лабораторні, інструментальні обстеження та верифіковано діагноз гострий калькульозний холецистит. Операційне втручання проводили лапароскопічним методом. Прихильними вважали хворих, які набрали 4-3 бали, а неприхильними - 0-2. Оцінку коморбідності проводили за допомогою спеціального індексу - індексу коморбідності Charlson (M. E. Charlson, 1987).

Результати досліджень та їх обговорення. Індекс коморбідності Чарльстона в середньому склав $(3,91 \pm 1,9)$ бала. Більшість хворих мала індекс коморбідності на рівні 3-5 балів, що вказує на наявність супутньої патології у більшості пацієнтів. Серед супутніх захворювань переважали захворювання серцево-судинної системи: перенесений інфаркт міокарда - 11 (2,5 \%) хворих, гіпертонічна хвороба - 41 (9 \%) хворий, ішемічна хвороба серця - 132 (29 \%) хворі, серцеві аритмії - 173 (38 \%) хворі, застійна серцева недостатність - 18 (4 \%) хворих. Отже, прогнозуючи летальність досліджуваної когорти хворих, яким проводили холецистектомію, можна передбачити найвищі її показники із супутньою серцево-судинною та легеневою патологією, меншою мірою із варикозною хворобою та цукровим діабетом. 3 віком індекс коморбідності зростає, причому перебіг супутніх захворювань погіршується та зростає ризик ускладнень.
\end{abstract}

Ключові слова: гострий калькульозний холецистит; коморбідність; лапароскопічна холецистектомія.

Постановка проблеми і аналіз останніх досліджень та публікацій. За останні роки продовжується невпинне зростання хворих на гострий калькульозний холецистит (ГКХ), у тому числі $з$ ускладненим перебігом захворювання на тлі супутньої патології. Летальність після екстрених операцій, виконаних із приводу ускладнень шлунково-кишкових захворювань у осіб похилого віку, складає близько 15 \%, що дає змогу вважати поліморбідність (коморбідність) однією з найважливіших медико-соціальних проблем геріатричної та хірургічної практики. Саме у пацієнтів похилого віку коморбідність призводить до складної сумації симптомів, знижуючи їх звичну для лікаря діагностичну цінність або потенціюючи ці прояви, погіршує перебіг основного захворювання [1, 2]. Таким чином, вплив коморбідної патології на клінічні прояви, діагностику, прогноз і лікування багатьох захворювань багатогранний та індивідуальний. Поєднання захворювань, віку і лікарського патоморфозу значно змінюе клінічну картину і перебіг основної нозоології, у нашому випадку ГКХ, характер і тяжкість ускладнень, погіршує якість життя хворого, обмежує або утруднює лікувально-діагностичний процес [3, 4].

Коморбідність впливає на прогноз життя, підвищує вірогідність летальності. В межах поліморбідності жовчнокам'яна хвороба займає особливе місце, суттєво погіршуючи загальний стан хворих: такі пацієнти мають гірші показники якості життя і функціональної активності. Тому проблема лікування жовчнокам'яної хвороби на сьогодні $\epsilon$ актуальною [5, 6]. В економічно розвинених країнах холецитектомія залишається найбільш частою операцією, що виконується. 3 появою мініінвазивних хірургічних технологій в лікуванні жовчнокам'яної хвороби спостерігається чітка закономірність значного зменшення кількості традиційних холецистектомій, що, здається, повинно було б позитивно вплинути на основні статистичні показники (рівень післяопераційної летальності, число ускладнень та ін.) і в результаті на якість життя оперованих хворих - основному об'єктивному критерії ефективності і якості наданої медичної допомоги. Ускладнення, пов'язані з традиційною лапаротомією (нагноєння рани, евентрація, дихальні розлади, формування вентральних гриж та ін.), виникають у 9-12 \% хворих [7, 8].

Незважаючи на це, в останні роки не спостерігається суттєвого зниження кількості післяопераційних ускладнень і летальності, зменшення числа екстрених операцій, більше того, частота інтраопераційних ускладнень при використанні мініінвазивних методів хірургічного лікування жовчнокам'яної хвороби, за даними авторів, дещо зросла. Це, очевидно, пов’язано з високим індек- 


\section{З ДОСВІДУ РОБОТИ}

сом коморбідності. У зв'язку з викладеними фактами актуальне вивчення частоти наявності і рівня коморбідності у хворих із ГКХ на основі об’єктивних критеріїв оцінки ефективності хірургічного втручання та врахування індексу коморбідності у хворих з цією патологією.

Мета роботи: встановлення частоти наявності і рівня коморбідності у хворих із ГКХ, яким проводили лапароскопічну холецистектомію.

Матеріали і методи. Прооперовано 457 хворих на гострий калькульозний холецистит віком від 20 до 89 років, у середньому $(64,5 \pm 9,74)$ роки (77 \% жінки та 23 \% чоловіків), які перебували на стаціонарному лікуванні в міській лікарні № 2 м. Тернополя. Усім проведено клініко-лабораторні, інструментальні обстеження та верифіковано діагноз ГКХ. Операційне втручання проводили лапароскопічним методом. Прихильними вважали хворих, які набрали 4-3 бали, а неприхильними 0-2. Оцінку коморбідності проводили за допомогою спеціального індексу - індексу коморбідності Charlson (M. E. Charlson, 1987), який являє собою бальну оцінку (від 0 до 40) наявності певних супутніх захворювань та використовується для прогнозу летальності у найближчі 10 років [7, 8]. При його розрахунку підсумовували бали, що відповідають певним супутнім захворюванням та додається ще 1 бал на кожні 10 років після 40-річного віку (40-49 років - 1 бал; 50-59 років - 2 бали і т. д). Кількість балів, яку отримали, дає можливість провести прогноз смертності, яка при відсутності коморбідності складає 12 \%; при 1-2 бали 26 \%; 3-4 - 52 \%, а при сумі більше 5 балів - 85 \%. Використання індексів для оцінки коморбідності дає змогу якнайповніше оцінити загальний статус пацієнта - поширення захворювань, їх тяжкість, вплив на 10-річну виживаність, що варто враховувати при виборі лікувальної тактики ведення.

Статистичну обробку проводили за допомого пакета прикладних програм SPSS $®$ V.21.0 та редактора електронних таблиць Excel. Дані представлені у формі середнього значення і стандартної похибки середнього ( $\mathrm{M} \pm \mathrm{m})$. Достовірність відмінностей між групами за кількісними ознаками оцінювали за допомогою t-критерію Стьюдента (при нормальному розподілі), або в інших випадках використовували непараметричний ранговий критерії Манна - Уїтні. Відмінності вважали достовірними при рівні значимості >95 \%.

Результати досліджень та їх обговорення. Оцінюючи індекс коморбідності Чарльстона встановлено його високі показники, оскільки середній вік пацієнтів, які були включені в дослідження, становив $(64,5 \pm 9,74)$ року, максимальний досягав 89 років. Подібна вибірка вікової групи зумовила підвищення індексу коморбідності і підвищення летальності. Так, індекс коморбідності Чарльстона в середньому склав $(3,91 \pm 1,9)$ бала, його показники коливалися від 1 бала до 8-ми. На рисунку 1 представлено розподіл пацієнтів залежно від суми балів індексу коморбідності Чарльстона. Як свідчать дані, більшість хворих мали індекс коморбідності на рівні 3-5 балів, що вказує на наявність супутньої патології у більшості пацієнтів. Окрім цього, у 5-ти пацієнтів індекс Чарльстона становив лише 1 бал, а у 8-ми пацієнтів - 8 балів (серед супутньої патології ішемічна хвороба серця, гіпертонічна хвороба, цукровий діабет, варикозна хвороба вен нижніх кінцівок, хронічні захворювання легень і т. д.).

Значна кількість супутніх захворювань, з одного боку, ускладнює післяопераційний прогноз i визначає тип операційного втручання, а з іншої виявляє вплив на ранні та пізні ускладнення холецистектомії. Одночасно вік пацієнтів був основним фактором, що визначав коморбідність. Встановлено, що з віком індекс коморбідності Чарльстона підвищувався, що вказує на вищу частоту супутніх захворювань у пацієнтів старшого віку. Між показником віку та індексом коморбідності встановлений достовірний кореляційний зв’язок середньої сили $(\mathrm{R}=0,61 ; \mathrm{p}<0,05)$.

Серед супутньої патології найчастіше діагностували ішемічну хворобу серця (29 \%), гіпертонічну хворобу (9 \%), порушення ритму (38 \%), серцеву недостатність (4 \%), хронічну легеневу патологію (12 \%) та цукровий діабет (12 \%). Також у 22 \% пацієнтів було діагностовано гастроезофагальну рефлюксну хворобу, у 15 \% - виразкова хвороба, а у 18 \% - ожиріння. На рисунку 2 подано розподіл обстежуваних пацієнтів залежно від частоти супутніх захворювань.

Коморбідну патологію діагностовано в 181 пацієнта, які включені в першу групу і яким була проведена лапароскопічна холецистектомія (табл. 1). Другу групу склади 276 хворих без супутньої патології. Серед супутніх захворювань (табл. 2) переважали захворювання серцево-судинної системи: перенесений інфаркт міокарда - 11 (2,5 \%), гіпертонічна хвороба 41 - (9 \%), ішемічна хвороба серця 132 - (29 \%), серцеві аритмії - 173 (38 \%), застійна серцева недостатність - 18 (4 \%). Під час підготовки до операції стабілізували систолічний артеріальний тиск на цифрах 150 мм рт. ст. і нижче, виключали пацієнтів із фракцією викиду менше 55 \%, миготливої аритмії. Легеневу патологію спостерігали в 


\section{з ДОСВІДУ РОБОТИ}

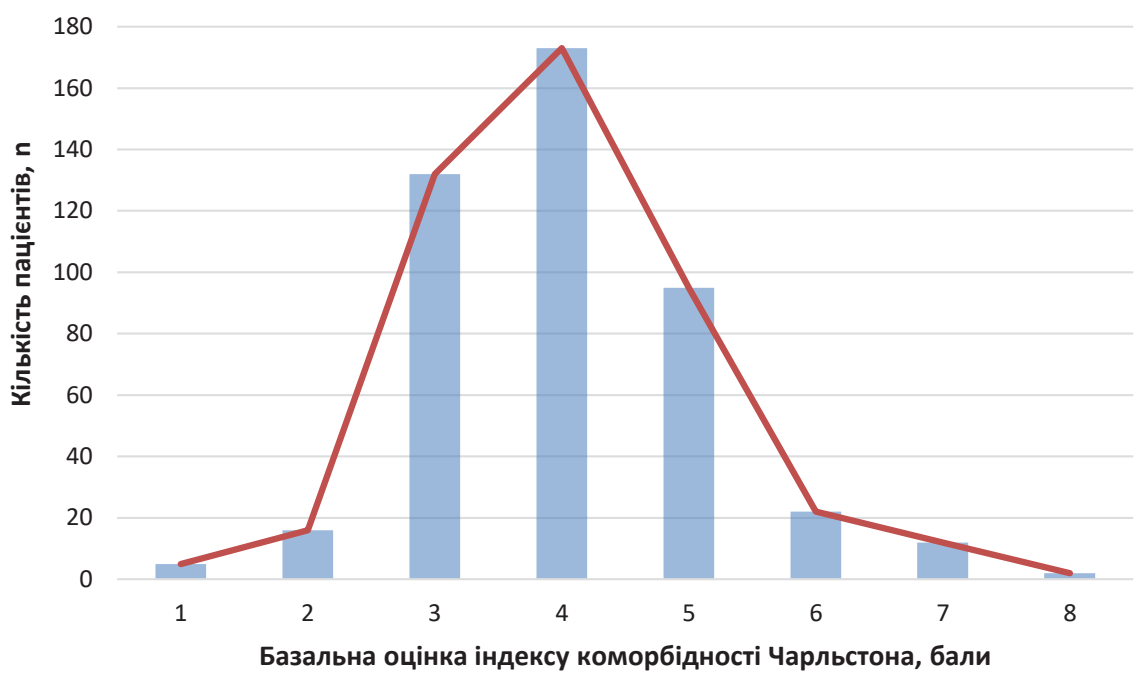

Рис. 1. Розподіл пацієнтів залежно від суми балів індексу коморбідності Чарльстона.

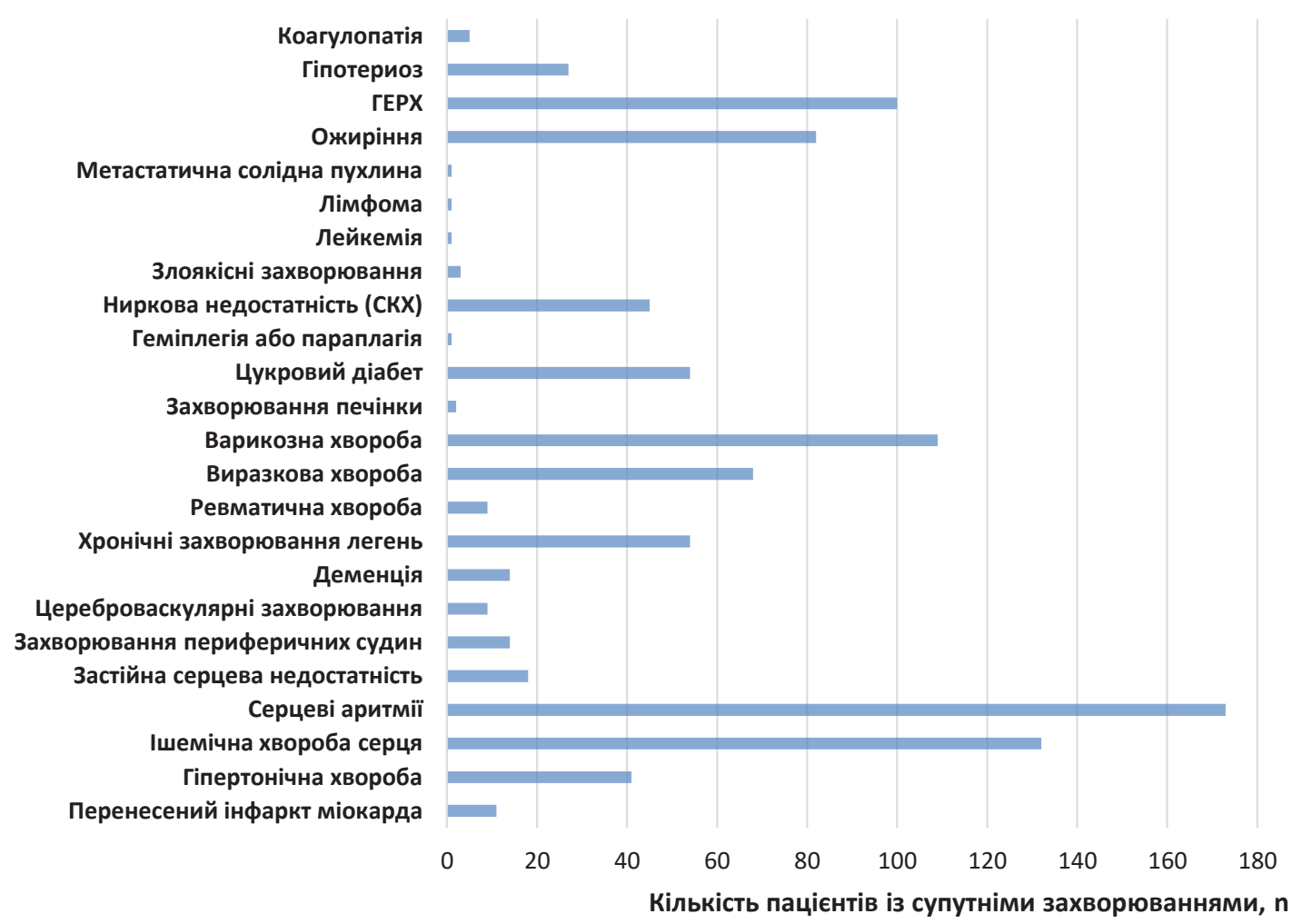

Рис. 2. Частота супутніх захворювань у пацієнтів із гострим калькульозним холециститом.

Таблиця 1. Розподіл пацієнтів за супутньою патологією та віком

\begin{tabular}{||l|c|c|c|c||}
\hline \multirow{2}{*}{ Наявність супутньої патології } & \multicolumn{3}{|c||}{ Вік, років } & \multirow{2}{*}{ Всього } \\
\cline { 1 - 4 } & $20-59$ & $60-74$ & $75-89$ & 276 \\
\hline Без супутніх захворювань & 248 & 28 & - & 181 \\
\hline Із супутніми захворюваннями & 21 & 124 & 36 & 457 \\
\hline Всього & 269 & 152 & 36 & \\
\hline \hline
\end{tabular}


Таблиця 2. Індекс коморбідності

\begin{tabular}{|c|c|c|c|}
\hline Параметри & $\begin{array}{c}\text { Загальна кількість, } \\
\text { n = } 457 \text { (\%) }\end{array}$ & $\begin{array}{c}\text { Індекс Чарльстона, } \\
\text { бали }\end{array}$ & $\begin{array}{c}\text { Прогноз летальності, \% } \\
\text { (10-річна виживаність) }\end{array}$ \\
\hline Перенесений інфаркт міокарда & $11(2,5)$ & 7,1 & 93 \\
\hline Гіпертонічна хвороба & 41 ( 9$)$ & 6,3 & 89 \\
\hline Ішемічна хвороба серця & 132 (29) & 6,5 & 90 \\
\hline Серцеві аритмії & $173(38)$ & 6,1 & 88 \\
\hline Застійна серцева недостатність & $18(4)$ & 6,1 & 88 \\
\hline $\begin{array}{l}\text { Захворювання периферичних } \\
\text { судин }\end{array}$ & $14(1)$ & 4 & 50 \\
\hline $\begin{array}{l}\text { Цереброваскулярні } \\
\text { захворювання }\end{array}$ & $9(2)$ & 4,1 & 52 \\
\hline Деменція & $14(1)$ & 3,7 & 49 \\
\hline Хронічні захворювання легень & $54(12)$ & 5,9 & 79 \\
\hline Ревматична хвороба & $9(2)$ & 2 & 31 \\
\hline Виразкова хвороба & $68(15)$ & 2,4 & 34 \\
\hline Варикозна хвороба & $109(24)$ & 5,4 & 85 \\
\hline Захворювання печінки & $2(0,5)$ & 3,1 & 45 \\
\hline Цукровий діабет & $54(12)$ & 5,1 & 71 \\
\hline Геміплегія або параплагія & $1(0,4)$ & 3,7 & 49 \\
\hline Злоякісні захворювання & $3(0,7)$ & 4 & 51 \\
\hline Лейкемія & $1(0,2)$ & 4 & 51 \\
\hline Лімфома & $1(0,2)$ & 3 & 44 \\
\hline Метастатична солідна пухлина & $1(0,4)$ & 5 & 85 \\
\hline $\begin{array}{l}\text { Гастроезофагеальна рефлюксна } \\
\text { хвороба }\end{array}$ & $100(22)$ & 1,7 & 21 \\
\hline Коагулопатія & $5(1,2)$ & 2,5 & 35 \\
\hline
\end{tabular}

54 хворих (12 \%). Захворювання шлунково-кишкового тракту в - 170 (37,5 \%) хворих: гастроезофагальна рефлюксна хвороба - у 11 (22 \%), варикозна хвороба - у 68 (15\%), захворювання печінки - у 2 (0,5 \%). Варикозну хворобу діагностували в 109 (29 \%) хворих, а цукровий діабет - у 54 (12 \%). Інші захворювання спостерігалися в поодиноких випадках: цереброваскулярні захворювання та ревматична хвороба у 9 (2\%) хворих, геміплегія у в $(0,4 \%)$, злоякісні захворювання у 3 (0,7 \%) хворих, коагулопатію - в 5 (1,2 \%). Індекс коморбідної патології був найвищим у хворих із серцево-судинними захворюваннями і становив $6,7 \pm 2,1$, 3 легеневою патологією $-5,9 \pm 1,9,3$ варикозною хворобою -

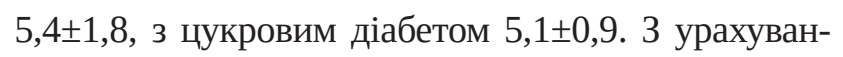
ням вікового фактора встановлено, що у старшій віковій групі (старше 70 років) коморбідність вище в 1,7 раза. Післяопераційна летальність становила 9,2 \%. Прогноз летальності (10-річна виживаність), враховуючи індекс коморбідності був найбільш несприятливий у хворих із супутньою серцево-судинною патологією і становив 93 \%, з легеневими захворюваннями - 86 \%, варикозною хворобою 79 \%, цукровим діабетом - $71 \%$.

Відразу зазначимо, що досі загальновизнаної міжнародної класифікації поєднаних захворювань або їх комбінацій створити поки що не вдалося. Однак характеристика даного поняття у хірургіч- 


\section{З ДОСВІДУ РОБОТИ}

них хворих, як і раніше, вивчена недостатньо і залишається на початковому етапі становлення. Як і раніше, сприйняття впливу супутніх захворювань на основне - хірургічне, розглядається як синдром взаємного обтяження без урахування спільності патогенетичних основ. Це суперечить розвитку клінічного мислення сучасного хірурга, який додав собі досягнення мініінвазивних та IT-технологій.
Висновок. Прогнозуючи летальність дослідної когорти хворих, яким проводили холецистектомію, можна передбачити найвищі її показники із супутньою серцево-судинною та легеневою патологією, меншою мірою із варикозною хворобою та цукровим діабетом. 3 віком індекс коморбідності зростає, причому перебіг супутніх захворювань погіршується та зростає ризик ускладнень.

\section{СПИСОК ЛІТЕРАТУРИ}

1. Dekker J. Exercise in people with comorbidity or multimorbidity / J. Dekker, B. M. Buurman, M. van der Leeden // Health Psychol. - 2019. - Vol. 38 (9). - P. 822-830. DOI: 10.1037/ hea0000750.

2. Ukegjini K. Diagnosis and treatment of acute cholecystitis / K. Ukegjini, B. M. Schmied // Ther Umsch. - 2020. - Vol. 77 (4). - P. 133-146. DOI: 10.1024/0040-5930/a001168.

3. Ранние послеоперационные осложнения у больных калькулезным холециститом и холедохолитиазом : монография / Красильников Д. М., Фаррахов А. 3., Хайруллин И. И., Маврин М. М. - Казань : Медицина, 2008. - 176 с.

4. Новик А. А. Исследование качества жизни в медицине / А. А. Новик, Т. И. Ионова. - Москва : ГЭОТАР-МЕД, 2004. - C. $112-120$.

5. Коморбидные и мультиморбидные состояния в гериатрии (обзор) / Арьева Г. Т., Советкина Н. В., Овсянникова Н. А., Арьев А. Л. // Успехи геронтологии. - 2011. - 24 (4). - С. 612-619. 6. Вёрткин А. Л. Коморбидность / А. Л. Вёрткин, А. С. Скотников // Лечащий врач. - 8. - С. 34-38.

\section{REFERENCES}

1. Dekker, J., Buurman, B.M., \& van der Leeden, M (2019). Exercise in people with comorbidity or multimorbidity. Health Psychology, 38 (9), 822-830.

2. Ukegjini, K., \& Schmied, B.M. (2020). Diagnosis and treatment of acute cholecystitis. Ther Umsch, 77 (4), 133-146.

3. Krasylnykov, D.M., Farrakhov, A.Z., Khairullyn, Y.Y., \& Mavryn, M.M. (2008). Rannye posleoperatsyonnye oslozhneniya u bolnykh kalkuleznym kholetsystitom i kholedokholitiazom [Early postoperative complications in patients with calculous cholecystitis and choledocholithiasis]. Kazan: Meditsina [in Russian]. 4. Novyk, A.A., Yonova, T.Y. (2004). Issledovanye kachestva zhyzny $v$ medytsyne [Study of quality of life in medicine]. Moscow: GEOTAR-MED, 112-120 [in Russian].

5. Areva, H.T., Sovetkyna, N.V., Ovsiannykova, N.A., \& Arev, A.L. (2011). [Komorbidnye i multymorbidnye sostoyaniya v geriatiu (obzor)]. Comorbid and multimorbid conditions in geriatrics (review). Uspekhy gerontologii - Advances in Gerontology, 24 (4), 612-619 [in Russian].

6. Vërtkyn, A.L., \& Skotnykov, A.S. (2013). Komorbidnost [Comor-

bidity]. Lechashchiy vrach - The Physician, 8, 34-38 [in Russian].

7. Gomes, C.A., Junior, C.S., Di Saverio, S., Sartelli, M., Kelly, M.D. et al. (2017). Acute calculous cholecystitis: Review of current best practices. World Journal of Gastrointestinal Surgery, 9 (5), 118-126.

8. Lauro, A., Cervellera, M., D'Andrea, V., Casella, G., \& Di Matteo, F.M. (2019). Impact of cardiovascular/diabetic comorbidity on conversion rate during laparoscopic cholecystectomy for acute cholecystitis: a multi-center study on early versus very delayed approach. Giornale di Chirurgia, 40 (2), 95-104.

9. Charlson, M.E., Pompei, P., \& Ales, K.L. (1987). A new method of classifying prognostic comorbidity in longitudinal studies: development and validation. Journal of Chronic Diseases, 40, 373-383.

10. Tuty Kuswardhani, R.A., Henrina, J., Pranata, R., Anthonius Lim, M., Lawrensia, S., Suastika, K. (2020). Charlson comorbidity index and a composite of poor outcomes in COVID-19 patients: A systematic review and meta-analysis. Diabetology \& Metabolic Syndrome, 14 (6), 2103-2109. 
N. A. MELNYK, YU. V. ZAPOROZHETS, D. V. OSADCHUK, O. I. DZIUBANOVSKYI, S. R. PIDRUCHNA

I. Horbachevsky Ternopil National Medical University

\section{ASSESSMENT OF COMORBIDITY IN PATIENTS WITH ACUTE CALCULOUS CHOLECYSTITIS WITH LAPAROSCOPIC CHOLECYSTECTOMY}

The aim of the work: to establish the frequency and level of comorbidity in patients with acute calculous cholecystitis (ACC), who underwent laparoscopic cholecystectomy.

Materials and Methods. 457 patients with ACC who were hospitalized in the City Hospital No. 2 in Ternopil were operated on. All of them underwent clinical and laboratory, instrumental examinations and verified the diagnosis of ACC. The surgery was performed laparoscopically. Patients who scored 4-3 points were considered favorable, and 0-2 points were unfavorable. Comorbidity was assessed using a special index, the Charlson Comorbidity Index (M. E. Charlson, 1987).

Results and Discussion. The Charleston comorbidity index averaged (3.91 \pm 1.9$)$ points. Most patients had a comorbidity index of 3-5 points, which indicates the presence of concomitant pathology in the vast majority of patients. Concomitant diseases were dominated by diseases of the cardiovascular system: myocardial infarction 11 (2.5\%), hypertension 41 (9\%), coronary heart disease 132 (29\%), cardiac arrhythmias 173 (38 \%), congestive heart failure 18 (4\%). Thus, predicting the mortality of the studied cohort of patients who underwent cholecystectomy, we can predict the highest rates with concomitant cardiovascular and pulmonary pathology, to a lesser extent with varicose veins and diabetes. With age, the comorbidity index increases, and the course of comorbidities worsens and the risk of complications increases.

Key words: acute calculous cholecystitis; comorbidity; laparoscopic cholecystectomy. 